\title{
Pathology of 'pseudotumours' of the orbit: A review
}

\author{
A. GARNER \\ From the Department of Pathology, Institute of Ophthalmology, London
}

The term pseudotumour of the orbit is unfortunate, since it merely purports to describe a negative quality of a considerable number of diverse pathological conditions. Among ophthalmologists it is common practice to limit the term to those lesions which are of an idiopathic inflammatory nature (Blodi and Gass, 1967), whereas Birch-Hirschfeld, who introduced the term, included all non-neoplastic disorders (Birch-Hirschfeld, 1905). Not only is the term open to arbitrary definition of this kind but it confers the dubious status of a diagnostic label on a group of conditions whose nature is often almost entirely shrouded in mystery. Easton and Smith (1961) proposed the alternative term non-specific granuloma of the orbit but this describes only a minority of intraorbital inflammatory lesions and consequently is of limited application.

Most non-neoplastic orbital swellings are reactive and as such can be due to infection, parasitic infestation, foreign-body reaction, and a variety of allergic disorders. Moreover, while many are purely orbital lesions, others appear as part of a more widespread disorder. Only in a minority of cases, however, can a specific cause be implicated, the rest posing one of the major unsolved problems of ocular pathology.

\section{Classification}

A logical way to classify the diverse disorders of the orbit which clinically may simulate neoplasia is to divide them into lesions of known aetiology, both localized and systemic, and an idiopathic group as recommended by Zimmerman (1967) and shown in the table. With regard to the first two groupings it has to be emphasized that the application of a diagnostic label does not necessarily imply an understanding of either aetiology or even pathogenesis, although something of the behaviour of the disease and consequent prognosis is generally known.

Received for publication 7 June 1973.

\begin{tabular}{|c|c|}
\hline Group & Type \\
\hline $\begin{array}{l}\text { Localized orbital swelling } \\
\text { of known pathogenesis }\end{array}$ & $\begin{array}{l}\text { Bacterial infection } \\
\text { Paranasal sinusitis } \\
\text { Dental abscess } \\
\text { Haematogenous } \\
\text { Viral infection } \\
\text { Fungal infection } \\
\text { Parasitic infestation } \\
\text { Lipogranuloma } \\
\text { Epidermoid and dermoid cysts } \\
\text { Cholesterol granuloma } \\
\text { Foreign body granuloma } \\
\text { Amyloid } \\
\text { Sclerosing angioma } \\
\text { Nodular fasciitis } \\
\text { Haematoma } \\
\text { Fibrous dysplasia (monostotic) }\end{array}$ \\
\hline $\begin{array}{l}\text { Orbital swelling of known } \\
\text { pathogenesis occurring as } \\
\text { part of a systemic disorder }\end{array}$ & $\begin{array}{l}\text { Wegener's granulomatosis } \\
\text { Midline lethal granuloma } \\
\text { Polyarteritis nodosa } \\
\text { Dermatomyositis } \\
\text { Sjögren's syndrome } \\
\text { Sarcoidosis } \\
\text { Histiocytosis } \\
\text { Eosinophilic granuloma of bone } \\
\text { Schüller-Christian disease } \\
\text { Other } \\
\text { Multifocal fibrosclerosis } \\
\text { Endocrine exophthalmos }\end{array}$ \\
\hline $\begin{array}{l}\text { Idiopathic inflammatory } \\
\text { swelling confined to the } \\
\text { orbit }\end{array}$ & $\begin{array}{l}\text { Granulomatous } \\
\text { Diffuse chronic inflammation } \\
\text { Lymphoid hyperplasia } \\
\text { Sclerosing } \\
\text { Dacryoadenitis } \\
\text { Myositis }\end{array}$ \\
\hline
\end{tabular}

Table Classification of non-neoplastic orbital swellings

Non-neoplastic Swelling of Known Type Confined to the Orbit

\section{BACTERIAL INFECTION}

An association between paranasal sinus infection and orbital inflammation is well recognized, spread occurring directly or via the vascular drainage (Williamson-Noble, 1954; Coop, 1961; and many others). Orbital cellulitis, or less commonly orbital abscess, culminating in dense reactive scar tissue formation is usual and according to WilliamsonNoble (1954) used to be responsible for as many as $70 \%$ of so-called pseudotumours. The percentage is probably considerably less today. 
Direct spread from an infected tooth socket (Benedict and Knight, 1923; Blagojević, Stefanović, Piščević, and Radosavljević, 1969) or focus of chronic osteomyelitis (Benford and Brunner, 1947) is also recognized. Tuberculous granuloma and syphilitic gumma and periostitis are now exceptionally rare but not unknown (Ursan and Ghidrai, 1957; Cernea, Marculescu, and Constantin, 1968). Metastatic orbital infection as a complication of septicaemia has been recorded by Benedict (1949a).

VIRAL INFECTION

Orbital inflammation due to viral infection has been postulated on circumstantial grounds (Ardouin, Ferrand, Feuvrier, and Bernard, 1967) but as yet virus particles have not been demonstrated.

\section{FUNGAL INFECTION}

There have been a number of reports of granulomatous orbital inflammation due to fungal infection. Aspergillosis appears to be one of the most common types (Agarwal, Dayal, and Agrawal, 1964; Green, Font, and Zimmerman, 1969; and many others). Mucormycosis of the orbit usually originates in the paranasal sinuses and is commonly associated with either prolonged antibiotic administration (Blodi, Hannah, and Wadsworth, 1969) or poorly controlled diabetes mellitus (Fleckner and Goldstein, 1969). Other fungal granulomata have included actinomycosis (Bobrova, 1954; Veirs and Davis, 1958), histoplasmosis (Olurin, Lucas, and Oyediran, 1969), and coccidioidomycosis (Wilson and Plunkett, 1965). The prognosis for all fungal infections of the orbit is often poor because of the risk of cerebral spread.

\section{PARASITIC INFESTATION}

Tape worms are perhaps the commonest orbital parasite, hydatid cyst following echinococcus infestation in endemic areas (Handousa, 1951; Baghdassarian and Zahkaria, 1971) and cysticercosis due to ingestion of Taenia solium (Malik, Gupta, and Choudhry, 1968) both being well documented. Other parasitic granulomata have included dirofilariasis (Brumback, Morrison, and Weatherly, 1968) bilharzia, ascariasis, and amoebiasis (Mortada, 1968), and onchocerciasis (fig 1).

\section{LIPOGRANULOMA}

Orbital lipogranuloma was clearly defined by Coop (1961) as a type of so-called pseudotumour in which the granulomatous reaction is apparently aimed at the adipose tissue of the orbit and is considered to represent a response to fat necrosis (fig 2). The origin of this self-limiting reaction, which culminates in reparative fibrosis (sclerosing

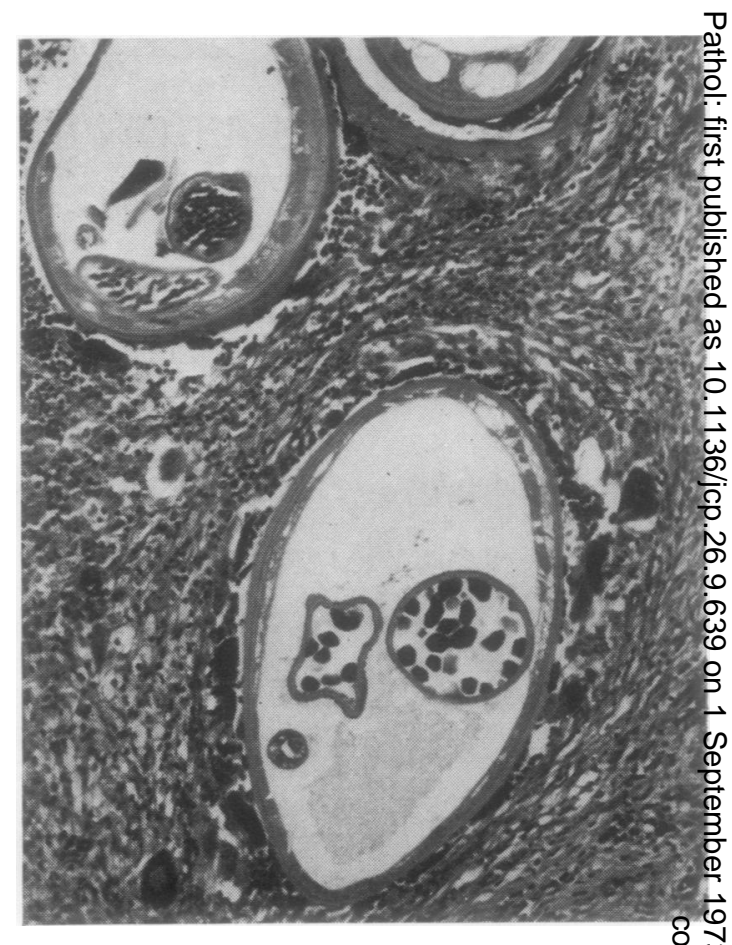

Fig 1 Orbital onchocerciasis. Segments of a mature worm are surrounded by chronic granulomatous tissue which includes epithelioid cells, multinucleated giant cells, lymphocytes, and eosinophils. $H \& E \times 120$

lipogranuloma) (fig 3), is usually unknown bu해 suggestions have centred in anoxia and toxicity? Although a systemic form of Weber-Christia disease (relapsing febrile nodular non-suppurative panniculitis) affecting multiple sites in addition to skin is recognized (Milner and Mitchinson, 1965 orbital involvement has not as yet been described. Lipogranuloma in the orbit as a complication of radiography involving the use of lipid-based contrast media is recorded (Zizmor, 1966; Eifrig, 1968 and has been seen following grease gun injur (fig 4).

\section{CHOLESTEROL GRANULOMA}

Organization of an intraorbital haematoma can om occasion be associated with a foreign-body giant cell reaction to residual cholesterol. Haemosideri⿹ is also usually present.

\section{EPIDERMOID CYST (CHOLESTEATOMA)}

Epidermoid cysts in the orbit are fairly uncommon (Carey, 1958; Silletti, 1967) and develop from ectopic epithelial rests or as a result of accidenta implantation. The cysts are lined by squamo 


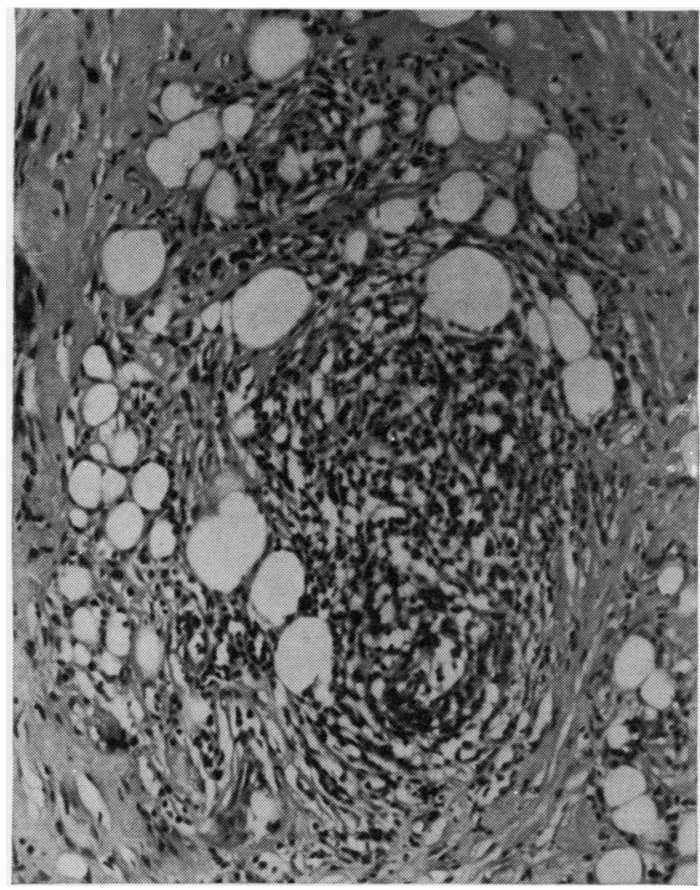

Fig 2

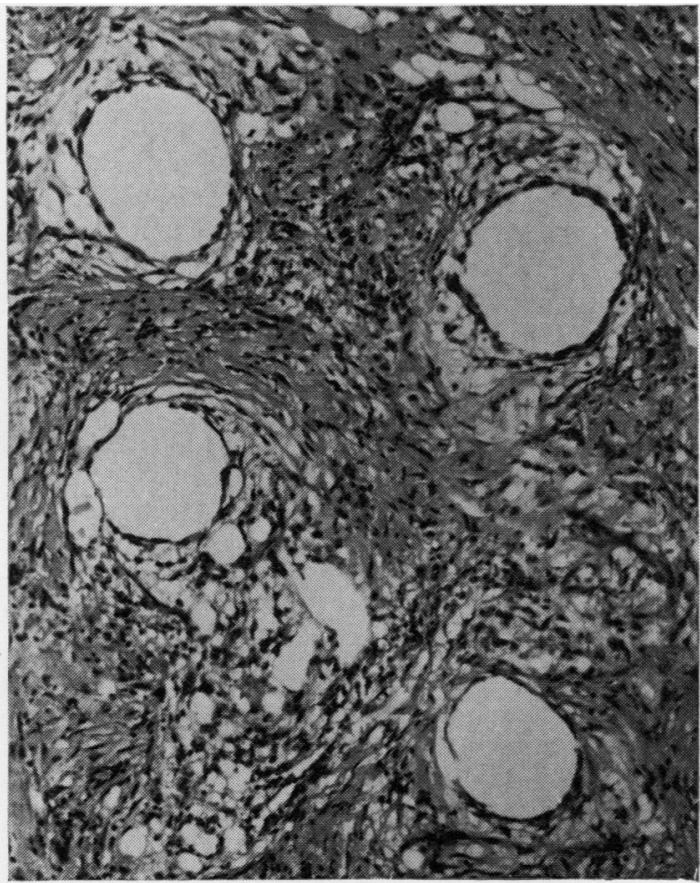

Fig 4

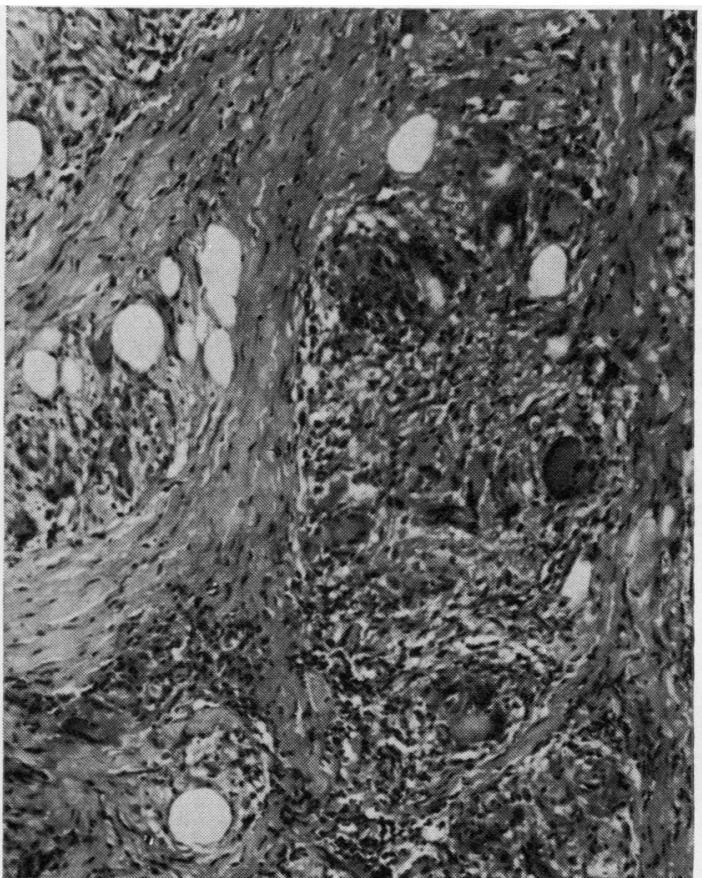

Fig 3

Fig 2 Lipogranuloma of the orbit. The inflammatory reaction is chiefly around groups of disrupted fat cells and consists of lymphocytes, macrophages, and occasional multinucleated giant cells. $H \& E \times 120$

Fig 3 Sclerosing lipogranuloma. Eventually the foci of fat necrosis undergo reparative fibrosis although granulomatous areas may persist for long periods. $H \& E \times 120$

Fig 4 Orbital lipogranuloma resulting from a grease gun injury. The oil globules are surrounded by lipidcontaining macrophages and chronic inflammatory cells. $H \& E \times 120$ 
epithelium and filled with keratinous material: although cholesterol crystals may also be present the term 'cholesteatoma', which is sometimes applied to these cysts, has little to commend it. Moreover, orbital epidermoid cysts have a much more favourable prognosis than the so-called cholesteatomas of the middle ear.

\section{DERMOID CYST}

Dermoid cysts are lined by both epidermis and dermal glandular structures, and consequently contain not only keratin but also sebaceous secretion including cholesterol. Besides having been mistaken for orbital neoplasia when in the intact state (MacDonald and Byers, 1959), rupture of the cyst can occur allowing the retained material to leak out and provoke a granulomatous inflammatory reaction (Coop, 1961; Blodi and Gass, 1967).

\section{AMYLOIDOSIS}

Localized amyloid deposition as a long-term complication of chronic inflammation and scartissue formation is well documented in the conjunctiva (Mathur and Mathur, 1959; Smith and Zimmerman, 1966) and cornea (McPherson, Kiffney, and Freed, 1966; Garner, 1969). Orbital lesions, possibly formed on a similar basis, have been recorded on occasion (Easton and Smith, 1961; Kassman and Sundmark, 1967; Raab, 1970), while Goder and Velhagen (1968) havenoted amyloid as a sequel to trachomatous inflammation. There does not appear to be any record of orbital deposition in generalized amyloidosis.

SCLEROSING ANGIOMA

Despite its name few now regard this lesion, alternatively known as dermatofibroma or histiocytoma, as a true neoplasm. As the multiplicity of names indicates, the histogenesis of this fibrosing and richly vascularized condition commonly associated with lipid-filled foam cells and haemosiderin deposition is obscure. Orbital involvement has been observed on a number of occasions (Guerra, 1962; Blodi and Gass, 1967). There is no doubt, however, that rarely sclerosis of an undisputed angioma may be seen.

NODULAR FASCIITIS

Bearing a superficial resemblance to fibrosarcoma, this self-limiting and possibly inflammatory lesion was first defined in 1955 by Konwaler, Keasbey, and Kaplan. Since then there have been a handful of reports of its occurrence around the eye, chiefly in the conjunctiva and anterior episclera (Font and Zimmerman, 1966; Tolls, Mohr, and Spencer, 1966). The involvement of the orbital connective tissue is, however, on record (Levitt, de Veer, andF Oguzhan, 1969). Complete cure following loca? excision is invariable and, if the pattern of behaviou $\vec{F}^{*}$ common to skin lesions is applicable, it can be predicted that many of the orbital lesions wouls similarly undergo spontaneous regression if lef alone.

FOREIGN-BODY GRANULOMA

Orbital granuloma following the entry of a foreign body, including the introduction of talc in the course of surgical procedures (McCormick $\omega_{\text {W }}$ Macaulay, and Miller, 1949), has been described op several occasions (Stallard, 1940; Paufique and Etienne, 1953; Coop, 1961). Foreign-body granu@ lomas may account for at least some of the so 0 called solitary sarcoid lesions of the orbit and it is advisable to examine multiple sections from suclo cases for evidence of birefringent material.

FIBROUS DYSPLASIA OF BONE

Involvement of the bony orbit by fibrous dysplasid is a fairly rare cause of proptosis which present? most often in adolescence or early adulthood (King and Hayes, 1951). Although more than one bone in the wall of the orbit may be affected disseminated involvement is uncommon.

\section{Inflammatory Swelling Occurring as Part Systemic Disorder}

WEGENER'S GRANULOMATOSIS Godman and Churg (1954) defined the pathologica features of Wegener's granulomatosis as a triad of necrotizing granulomata of the respiratory tract disseminated necrotizing vasculitis involving botk arteries and veins, and necrotizing glomerulitie developing ultimately into a granulomatous nephritisoLess commonly other tissue can be involved an£. Straatsma (1957) drew attention to the ocula8 aspects of the disease: in six of 44 cases confirmec at necropsy he described orbital granulomats associated with similar lesions in the nose and paranasal sinuses. Although for patients with this. disease the orbital involvement is amongst the least of their problems, it is of some importance that Blodi and Gass (1967) should find that of 148 cases of apparently uncomplicated orbital 'pseudo tumours' six eventually proved to be suffering frono Wegener's granulomatosis. Moreover, retrospective review of these cases failed to show any of the histological stigmata such as multinucleated gianf cells (fig 5) and necrotizing vasculitis (fig 6) whicho might have raised suspicions of a Wegener's diathesiso While it would be hazardous to diagnose Wegener' $\mathrm{Q}$ granulomatosis in the absence of systemic disturb 


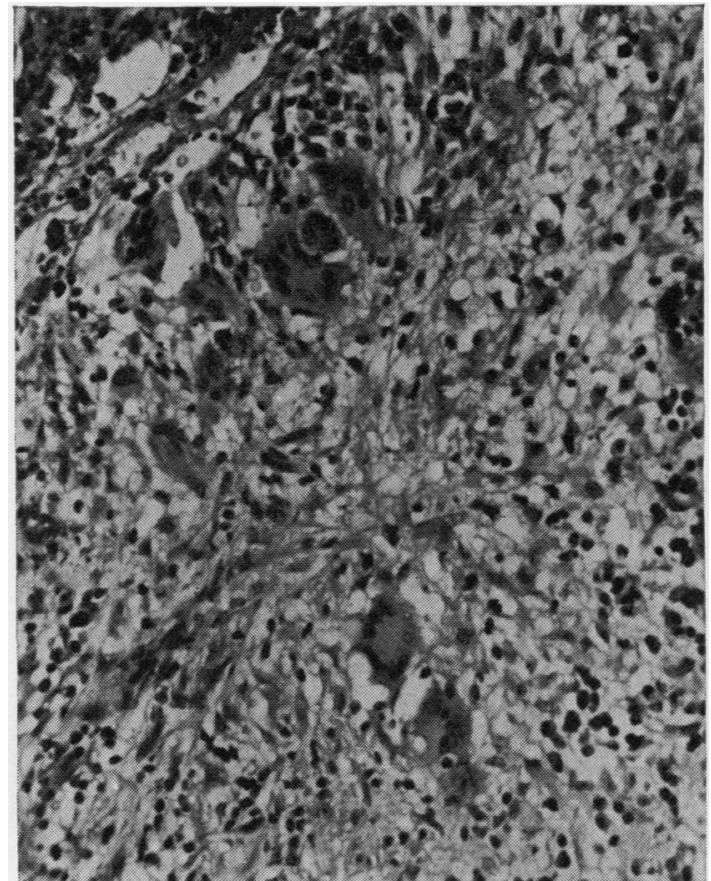

Fig 5

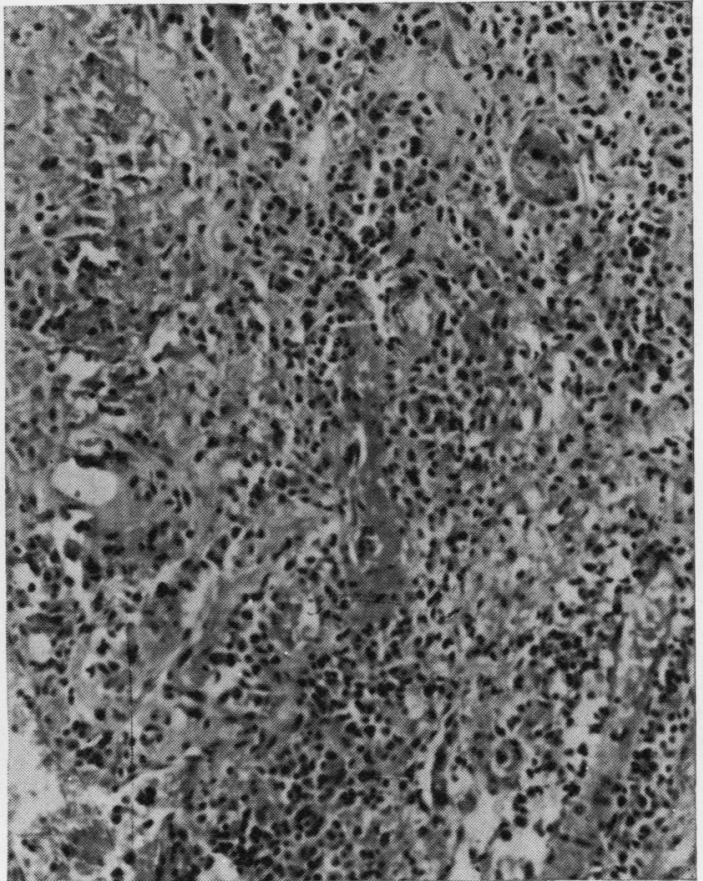

Fig 6

Fig 5 Wegener's granulomatosis. Orbital granulomata are usually, though not invariably, associated with involvement of the paranasal sinuses. In this instance the chronic inflammatory tissue includes several multinucleated giant cells as well as scattered eosinophils. $H \& E \times 190$

Fig 6 Wegener's granulomatosis. At the centre of the picture there is a necrotic vessel showing fibrinous insudation and surrounded by leucocytes. $H \& E \times 150$

ance, the experience of the above workers does mean that careful periodic review of patients with granulomatous orbital inflammation, particularly when it is bilateral, should be carried out.

Latterly a limited form of Wegener's granulomatosis in which renal involvement does not occur, and which has a relatively better prognosis, has been described (Carrington and Liebow, 1966; Cassan, Coles, and Harrison, 1970). As yet there is only a single report of orbital involvement in this limited form, and that concerned a patient with bilateral orbital lesions who was still alive 15 years after diagnosis (Cassan, Divertie, Hollenhorst, and Harrison, 1970). Even more recently Liebow, Carrington, and Friedman (1972) have documented a multisystemic condition bearing some affinity to the limited form of Wegener's granulomatosis, but differing chiefly with regard to the inclusion of neurological disturbance in a proportion of cases, the absence of upper respiratory tract involvement, and the tendency for many of the granulomata to mimic lymphomata. Indeed, in a minority of patients true lymphoma may develop in the later stages of the disease. It will be interesting to see whether orbital lesions can complicate this variant.

Midline lethal granuloma or midline malignant reticulosis (Kassel, Echevarria, and Guzzo, 1969) fundamentally affects the mucosa of the upper respiratory tract and may be a further variant of classical Wegener's granulomatosis (Friedmann, 1964). There is, however, a greater tendency for lymphoid neoplasia to supervene (Walton, 1960), and in this respect it is comparable to mycosis fungoides of the skin. Cutler and Blatt (1956) and Straatsma (1957) were among the first to describe examples of this condition with orbital involvement.

In none of these conditions is the aetiology known or the pathogenesis understood, although many consider that there is an immunological component which, it has been speculated, may be provoked by an initial virus infection with consequent alteration of tissue antigens (Liebow et al, 1972). 
POLYARTERITIS NODOSA

Chronic inflammation in the orbit associated with polyarteritis nodosa is unusual but not unknown. In a case reported by Walton (1959) the orbital lesion took the form of a non-specific extravascular granuloma, whereas in the case described by Van Wien and Merz (1963) there was arteritis without granuloma formation. In both cases the orbital lesion preceded the onset of generalized disease by several years.

\section{DERMATOMYOSITIS}

Involvement of the extraocular muscles in dermatomyositis is said to occur in about $10 \%$ of patients (O'Leary and Waisman, 1940). As a rule the affected muscles become wasted and show replacement fibrosis, but on occasion there can be inflammatory oedema which can present as an orbital mass sufficient to cause proptosis (Morgan, 1967).

There does not appear to be any record of orbital involvement in other connective tissue disorders.

\section{SJ ÖGREN'S SYNDROME}

Lacrimal gland inflammation characterized by marked lymphocytic infiltration and replacement of the gland parenchyma, resulting in failure of tear secretion and a dry eye, is an integral part of Sjögren's syndrome, a disease of suspected immune aetiology and one which is on record as predisposing to lymphoid neoplasia (Talal and Bunim, 1964). In uncomplicated cases, however, the associated parenchymatous atrophy means that lacrimal gland enlargement sufficient to produce significant orbital swelling is not usually a prominent feature, even though the salivary glands may be markedly enlarged.

\section{SARCOIDOSIS}

Ocular involvement in multifocal sarcoidosis is fairly common, an incidence of 30 to $40 \%$ having been quoted as an average (Nielsen, 1959). As a rule this takes the form of a granulomatous uveitis but on occasion there may be associated painless enlargement of the salivary and lacrimal glands (fig 7) to constitute one cause of the so-called Mikulicz syndrome. According to Nielsen (1959), the lacrimal glands may be enlarged in the absence of salivary involvement in about $8 \%$ of patients with sarcoidosis, and exceptionally orbital granulomata with minor or no lacrimal disease have been reported (Melmon and Goldberg, 1962).

In the absence of signs of generalized disease several other cases of alleged orbital sarcoidosis in the literature can only be accepted with considerable reserve (Benedict, 1949b; Knapp and Kroll, 1949; Stein and Henderson, 1956). Nevertheless, the

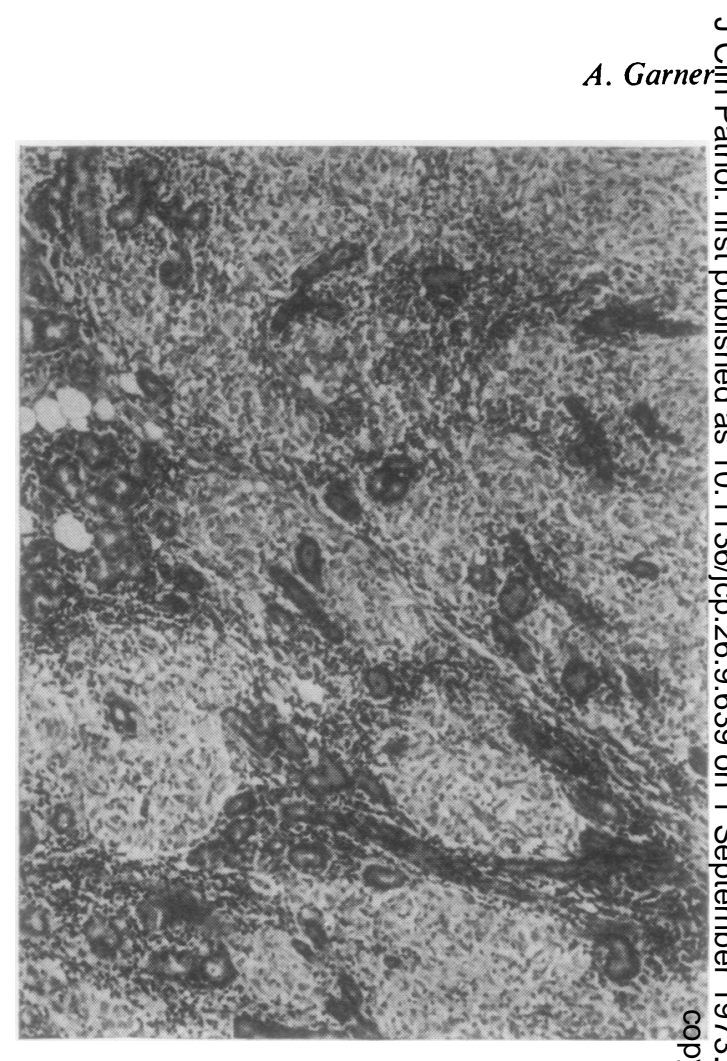

Fig 7 Sarcoidosis of the orbit. Usually, as in this instance, the characteristic non-caseating granulomata primarily involve the lacrimal gland. $H \& E \times 75$

possibility that a solitary sarcoid lesion may oc $\stackrel{\overrightarrow{\underline{0}}}{\overrightarrow{\underline{\sigma}}}$ casionally precede more widespread involvement should not be overlooked.

HISTIOCY T OSIS

Eosinophilic granuloma of bone, Schüller-Christian' disease, and Letterer-Siwe disease are widely held? to be intimately related histiocytic conditionsi with a common, if obscure, aetiology (Lichtenstein 1964). Correspondingly they are often groupedo together under the term histiocytosis X. Involvement of the bones of the orbit by both eosinophilic granuloma (Gross and Jacox, 1942; Wheeler, 1946; Straatsma, 1958; Babior, 1971) and Schüller-o Christian disease (Wheeler, 1931) can be complicated by spread of the granulomata into the orbita cavity. Recently Codling, Soni, Barry, and Martin-o Walker (1972) recorded an example of orbital and lid swelling due to an unusual histiocytic condition thought possibly to be an instance of the newly? defined entity of sinus histiocytosis with massive lymphadenopathy, in which the histiocytes areo typically vacuolated and may contain phagocytosed范 lymphocytes (Rosai and Dorfman, 1969). 
MULTIFOCAL FIBROSCLEROSIS

Dense orbital fibrosis sufficient to cause proptosis is sometimes linked to a similar sclerosing process in other tissues. Thus fibrous tissue proliferation in the orbit has been reported in association with mediastinal fibrosis (DuPont, Varco, and Winchell, 1968), sclerosing cholangitis (Wenger, Gingrich, and Mendeloff, 1965), and Riedel's thyroiditis (Andersen, Seedorff, and Halberg, 1963; Arnott and Greaves, 1965). We ourselves have observed the concomitance of orbital and retroperitoneal fibrosis. Methysergide, a serotonin analogue of use in the treatment of migraine, is able to provoke retroperitoneal fibrosis in certain individuals (Graham, 1967), but so far its use has not been remarked on in cases of orbital fibrosis. An autosomal recessive gene abnormality may be operative in some patients (Comings, Skubi, Van Eyes, and Motulsky, 1967).

DYSTHYROID (ENDOCRINE) EXOPHTHALMOS Currently there are few who would include endocrine exophthalmos with orbital pseudotumours, but this merely serves to show the arbitrariness and imprecision of the term. Commonly, but not invariably, bilateral the orbital swelling of thyroid dysfunction is due to round cell infiltration and oedema of the extraocular muscles. Muscle degeneration eventually ensues (Kroll and Kuwabara, 1966) and, although the precise mechanism is obscure, the frequency of raised antithyroid immunoglobulin titres (Fells, Doniach, and El Kabir, 1970) could mean that an autoimmune reaction is in some way responsible.

\section{Idiopathic Inflammatory Orbital Swellings}

As the list of defined diseases giving rise to orbital swellings increases so the numbers of idiopathic inflammatory lesions will decrease. The latter are the type of case discussed at length by Blodi and Gass (1967) and, although many of them have a characteristically sudden onset with clinical signs of inflammation and a favourable outcome, there is little reason, as the variable histological findings indicate, to regard such orbital swellings as constituting a single entity.

In some the inflammation is granulomatous and may, as has already been observed, raise suspicions of sarcoid or a foreign-body reaction. Equally the possibility that the orbital lesion is the initial manifestation of either Wegener's granulomatosis or a related condition should not be overlooked.

In the majority, however, the inflammatory cell infiltrate is diffuse and consists mainly of mature lymphocytes, with smaller numbers of plasma cells, macrophages, and eosinophil and neutrophil polymorphonuclear leucocytes. Lymphoid proliferation can sometimes be so intense as to raise the question of neoplasia (fig 8). The presence, albeit scanty, of other inflammatory cells, including Russell bodies and reticulum cells in the absence of Reed-Sternberg cells, which might otherwise suggest a diagnosis of Hodgkin's disease, is a useful pointer against malignancy (fig 9). So too is the finding of a follicular arrangement and of germinal centres in the lymphocytic aggregates (fig 10). In general, as Zimmerman (1964) stressed, it is unusual for genuine lymphoid neoplasia to present in the orbit in adults and it may well be that lymphosarcoma in this region has been overdiagnosed in the past. With reference to a like problem in lung pathology, Liebow et al (1972) are of the opinion that in the absence of widespread disease the best criterion for distinguishing pseudolymphoma composed largely of mature lymphocytes from lymphoma is whether regional lymph nodes are involved. One wonders whether this approach ought not to be applied to the orbital situation also.

If the lymphoproliferative disorders, whether of the orbit or elsewhere, can be thought to represent a continuous spectrum from reactive hyperplasia through benign neoplasia to malignant lymphoma with a multicentric distribution, then it should occasion no surprise that precise diagnosis will sometimes be impossible. Such cases are those which exhibit the histological features of a lymphoma, in the form of massive proliferation of a single cell type, in the absence of any detectable extraorbital lesion. While it may be entirely correct to call such lesions solitary lymphomata the term has no prognostic significance, since there is no way of distinguishing those lesions which will eventually become disseminated from those which will maintain a benign course. The safest approach is to regard such lesions as potential if not actual malignant neoplasms and to advise local radiotherapy with thorough examination, including haematological investigation and lymphangiography both before and at intervals thereafter. According to Lederman (1964), true orbital lymphomata respond dramatically to quite low doses of irradiation whereas purely reactive proliferations are much less sensitive and are best treated with corticosteroids.

In many instances the inflammation principally involves the orbital muscles. To what extent this represents a separate disorder is in some doubt: while Dunnington and Berke (1943) and François, Rabaey, and Evens (1956) have regarded orbital myositis as a separate lesion, others such as Blodi and Gass (1967) see little reason for the distinction. Certainly there is no ground for separation in 


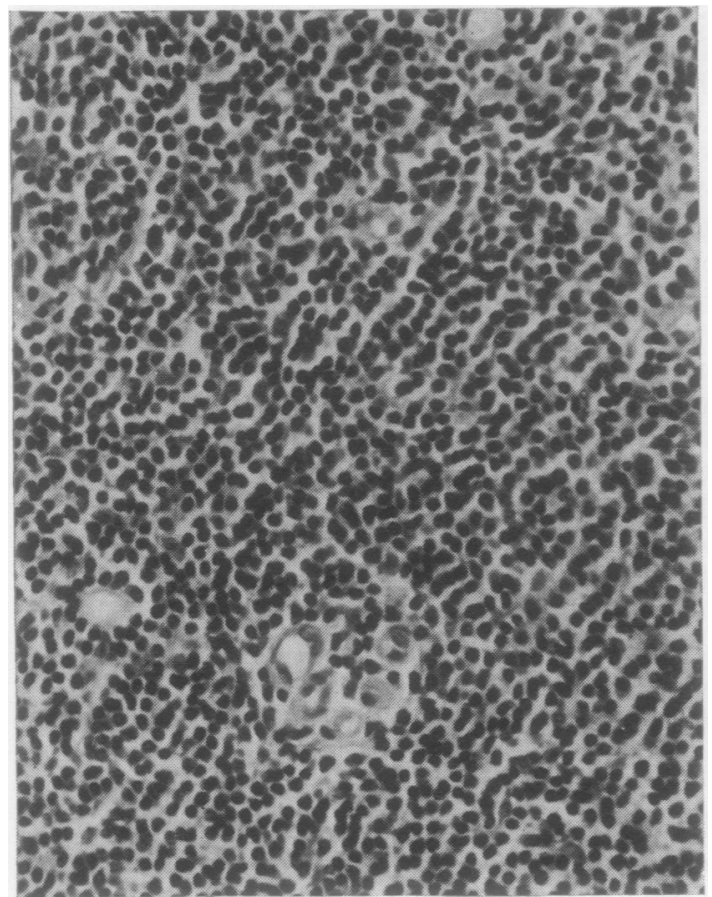

Fig 8

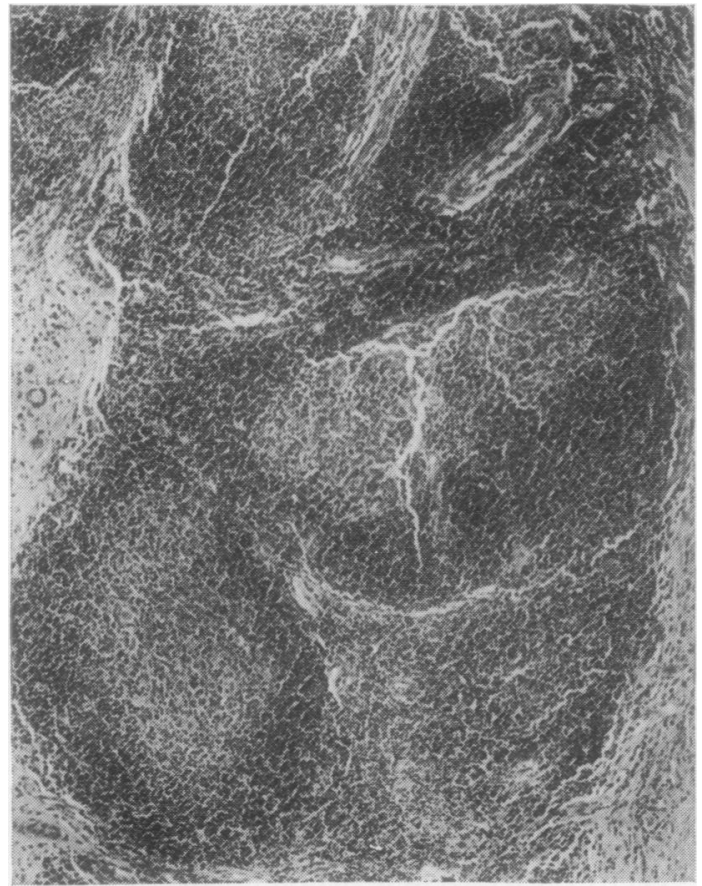

Fig 10

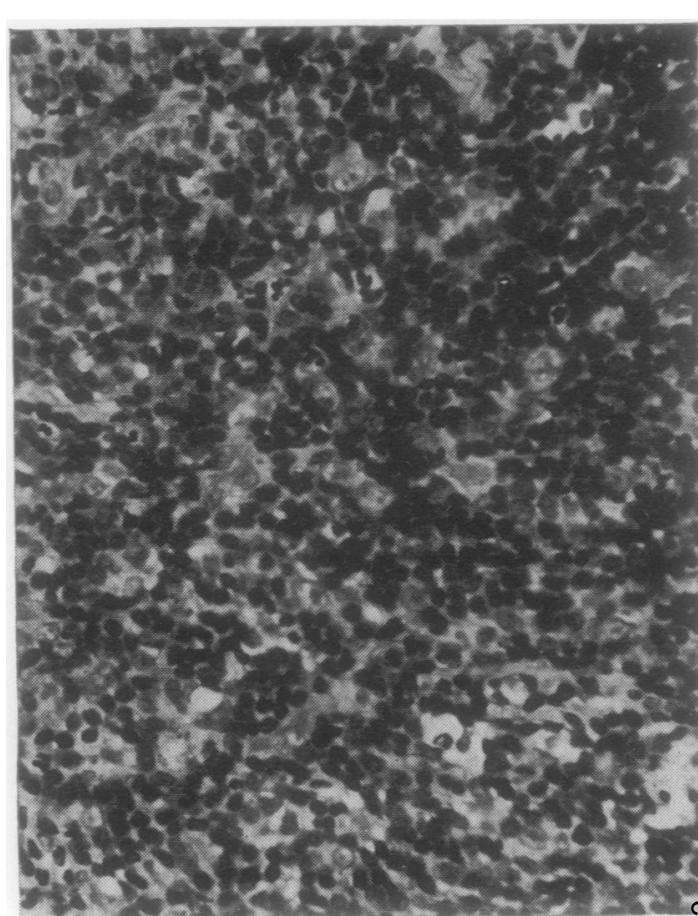

Fig 9

Fig 8 Lymphoid hyperplasia. This type of 'inflammatory pseudotumour' consisting of sheets of mature lymphocytes can be difficult to distinguish from malignant lymphoma and diagnosis should not be based on histological criteria alone. $H \& E \times 300$

Fig 9 Lymphoid hyperplasia. The finding of additional elements such as reticulum cells, plasma cells, and occasional polymorphs is strongly opposed to a diagnosis of neoplasia. $H \& E \times 300$

Fig 10 Lymphoid hyperplasia. The presence of follicles with germinal centres, as shown here, is also evidence of a reactive disorder. $H \& E \times 60$ 
terms of ultimate prognosis. Distinction from the myositis of endocrine exophthalmos does, however, need to be borne in mind because there are a few reports of unilateral proptosis diagnosed as pseudotumour of the orbit which were subsequently found to be due to unsuspected thyroid disease (Barkan, 1938; Agrawal, Dayal, and Agarwal, 1967). Dysthyroid myopathy, however, tends to show rather more oedema and less cellular infiltration than most idiopathic inflammatory lesions.

Diffuse inflammatory cell infiltration of the orbital fat is common and probably just part of a more widespread involvement in contradistinction to lipogranuloma which, as previously stated, is considered to be secondary to fat necrosis.

The lacrimal gland may be involved in many inflammatory conditions of the orbit but on occasion dacryoadenitis is the predominant feature, showing severe chronic inflammatory cell infiltration and extensive acinar destruction. In the vast majority of instances these remain solitary lesions but it is worth noting that Sjögren's syndrome has been reported as a late development. This complication seems to be particularly prone to occur when the lacrimal inflammatory infiltrate includes islands of myoepithelial proliferation (Font, Yanoff, and Zimmerman, 1967).

On occasion proptosis is related to a dense mass of hyalinized fibrous tissue in which only scanty inflammatory cells are seen. In many cases it is probable that the fibrosis is the end result of a chronic inflammatory process due to any one of a variety of causes, but, as Blodi and Gass (1967) comment, direct proof is missing. The coexistence of fibrosing lesions in other parts of the body, though unlikely, should not be overlooked.

By inference virtually nothing is known about the cause of these idiopathic inflammatory lesions of the orbit, but the possibility that they are the precursors of a systemic disorder must always be considered, particularly when the swelling is bilateral. In cases characterized by marked lymphoid proliferation or granuloma formation the concomitance of an immunological abnormality needs to be explored. Along sinilar lines it might be of value to investigate the further possibility that viral infection could modify both the orbital tissues and the lymphoid system so that an autoimmune reaction is provoked.

\section{References}

Agarwal, L. P., Dayal, Y., and Agrawal, P. K. (1964). Radical excision of a fungal granuloma (aspergillus) of the orbit. Orient. Arch. Ophthal., 2, 128-131.

Agrawal, P. K., Dayal, Y., and Agarwal, L. P. (1967). Pseudotumours of the orbit (a clinicopathological study). Orient. Arch. Ophthal., 5, 263-272.
Andersen, S. R., Seedorff, H. H., and Halberg, P. (1963). Thyroiditis with myxoedema and orbital pseucotumour. Acta ophthal (Kbh.), 41, 120-125.

Ardouin, M., Ferrand, B., Feuvrier, Y. M., and Bernard, J. (1967) Pseudo-tumour inflammatoire de l'orbite d'origine virale probable. Bull. Soc. ophthal. Paris, 67, 765-769.

Arnott, E. J., and Greaves, D. P. (1965). Orbital involvement in Riedel's thyroiditis. Brit. J. Ophthal., 49, 1-5.

Babior, S. N. (1971). Two cases of osseous forms of chronic xanthomatosis (Hand-Schüller-Christian disease). (Russian). Vestn. Oftal., 84 (2), 87-89.

Baghdassarian, S. A., and Zakharia, H. (1971). Report of three cases of hydatid cyst of the orbit. Amer. J. Ophthal., 71, 1081-1084.

Barkan, H. (1938). In discussion of a paper by P. M. Lewis on inflammatory pseudotumor of the orbit. Amer.J. Ophthal., 21, 996.

Benedict, W. L. (1949a). Diseases of the orbit. Trans. Amer. Acad. Ophthal. Otolaryng., 54, 26-36.

Benedict, W. L. (1949b). Sarcoidosis involving the orbit: report o two cases. Arch. Ophthal., 42, 546-550.

Benedict, W. L., and Knight, M. S. (1923). Inflammatory pseudotumor of the orbit. Arch. Ophthal. (N.Y.), 52, 582-593.

Benford, M. C., and Brunner, H. (1947). Involvement of the orbit in chronic inflammation of the frontal sinus. Amer. J. Ophthal. 30, 297-308.

Birch-Hirschfeld, A. (1905). Zur Diagnostik und Pathologie der Orbitaltumoren. Ber. dtsch. ophthal. Ges., 32, 127-135.

Blagojević, M., Stefanović, B., Piščević and Radosavljević, M. (1969). Phlegmon de l'orbite d'origine dentaire. Ophthalmologica (Basel), 157, 14-23.

Blodi, F. C., and Gass, J. D. M. (1967). Inflammatory pseudotumor of the orbit. Trans. Amer. Acad. Ophthal. Otolaryng., 71, 303-323.

Blodi, F. C., Hannah, F. T., and Wadsworth, J. A. C. (1969). Lethal orbito-cerebral phycomycosis in otherwise healthy children. Amer. J. Ophthal., 67, 698-705.

Bobrova, E. V. (1954). Actinomycosis of the orbit. (Russian). Vestn. Oftal., 33 (4), 39-40.

Brumback, G. F., Morrison, H. M., and Weatherly, N. F. (1968) Orbital infection with Dirofilaria. Sth. med. J. (Bgham, Ala.) 61,188 and 192.

Carey, P. C. (1958). Epidermoid and dermoid tumours of the orbit. Brit. J. Ophthal., 42, 225-239.

Carrington, C. B., and Liebow, A. A. (1966). Limited forms of angitis and granulomatosis of Wegener's type. Amer. J. Med., 41, 497-527.

Cassan, S. M., Coles, D. T., and Harrison, E. G., Jr. (1970). The concept of limited forms of Wegener's granulomatosis. Amer. J. Med., 49, 366-379.

Cassan, S. M., Divertie, M. B., Hollenhorst, R. W., and Harrison, E. G., Jr. (1970). Pseudotumor of the orbit and limited Wegener's granulomatosis. Ann. intern. Med., 72, 687-693.

Cernea, P., Marculescu, A., and Constantin, F. (1968). L'ostéopériostite syphilitique du sommet de l'orbite. Ann. Oculist. (Paris), 201, 436-442.

Codling, B. W., Soni, K. C., Barry, D. R., and Martin-Walker, W. (1972). Histiocytosis presenting as swelling of orbit and eyelid. Brit. J. Ophthal., 56, 517-530.

Comings, D. E., Skubi, K. B., Van Eyes, J., and Motulsky, A. G. (1967). Familial multifocal fibrosclerosis. Findings suggesting that retroperitoneal fibrosis, mediastinal fibrosis, sclerosing cholangitis, Riedel's thyroiditis, and pseudotumor of the orbit may be different manifestations of a single disease. Ann. intern. Med.. 66, 884-892.

Coop, M. E. (1961). Pseudotumour of the orbit: a clinical and pathological study of 47 cases. Brit. J. Ophthal., 45, 513-542.

Cutler, W. M., and Blatt, I. M. (1956). The ocular manifestations of lethal midline granuloma. Amer. J. Ophthal., 42, 21-35.

Dunnington, J. H., and Berke, R. N. (1943). Exophthalmos due to chronic orbital myositis. Arch. Ophthal., 30, 446-466.

DuPont, H. L., Varco, R. L., and Winchell, C. P. (1968). Chronic fibrous mediastinitis simulating pulmonic stenosis, associated with inflammatory pseudotumor of the orbit. Amer. J. Med., 44, 447-452.

Easton, J. A. and Smith, W. T. (1961). Non-specific granuloma of orbit ('orbital pseudotumour'). J. Path. Bact., 82, 345-354.

Eifrig, D. E. (1968). Lipid granuloma of the orbit. Arch. Ophthal., 79, $163-165$

Fells, P., Doniach, D., and El Kabir, D. J. (1970). Diagnosis of dysthyroid exophthalmos. Trans. ophthal. Soc. U.K., 90, 251-260. 
Fleckner, R. A., and Goldstein, J. H. (1969). Mucormycosis. Brit. J. Ophthal., 53, 542-548.

Font, R. L., Yanoff, M., and Zimmerman, L. E. (1967). Benign lymphoepithelial lesion of the lacrimal gland and its relationship to Sjögren's syndrome. Amer. J. clin. Path., 48, 365-376.

Font, R. L., and Zimmerman, L. E. (1966). Nodular fasciitis of the eye and adnexa. Arch. Ophthal., 75, 475-481.

François, J., Rabaey, M., and Evens, L. (1956). Myosites orbitaires chroniques. Ophthalmologica (Basel), 131, 105-120.

Friedmann, I. (1964). The pathology of midline granuloma. Proc. roy. Soc. Med., 57, 289-297.

Garner, A. (1969). Amyloidosis of the cornea. Brit. J. Ophthal., 53, 73-81.

Goder, G., and Velhagen, K. H. (1968). Amyloid in der Bindehaut und Orbita. Albrecht v. Graefes Arch. Ophthal., 176, 183-194.

Godman, G. C., and Churg, J. (1954). Wegener's granulomatosis: pathology and review of the literature. Arch. Path., 58, 533553.

Graham, J. R. (1967). Cardiac and pulmonary fibrosis during methysergide therapy for headache. Amer. J. med. Sci., 254, 1-12.

Green, W. R., Font, R. L., and Zimmerman, L. E. (1969). Aspergillosis of the orbit: report of ten cases and review of the literature. Arch. Ophthal., 82, 302-313.

Gross, P., and Jacox, H. W. (1942). Eosinophilic granuloma and certain other reticuloendothelial hyperplasias of bone. A comparison of clinical, radiologic, and pathologic features. Amer. J. med. Sci., 203, 673-687.

Guerra, R. (1962). Considerazioni su di un caso di angioma sclerosante dell'orbita. G. ital. Oftal., 15, 452-465.

Handousa, A. B. (1951). Proptosis caused by hydatid disease. Brit. J. Ophthal., 35, 607-613.

Kassel, S. H., Echevarria, R. A., and Guzzo, F. P. (1969). Midline malignant reticulosis (so-called lethal midline granuloma). Cancer (Philad.), 23, 920-935.

Kassman, T., and Sundmark, E. (1967). Orbital pseudo-tumours with amyloid. Acta ophthal. (Kbh.), 45, 220-228.

King, R. B., and Hayes, G. J. (1951). Unilateral proptosis due to fibrous dysplasia of bone. Arch. Ophthal., 46, 553-559,

Knapp, F. N., and Kroll, W. V. (1949). Sarcoid involving the orbit. Trans. Amer. ophthal. Soc., 47, 147-157.

Konwaler, B. E., Keasbey, L., and Kaplan, L. (1955). Subcutaneous pseudosarcomatous fibromatosis (fasciitis). Amer. J. clin. Path., 25, 241-252.

Kroll, A. J., and Kuwabara, T. (1966). Dysthyroid ocular myopathy: anatomy, histology, and electron microscopy. Arch. Ophthal., 76, 244-257.

Lederman, M. (1964). Radiation treatment of primary malignant tumors of the orbit. In Ocular and Adnexal Tumors: New and Controversial Aspects, edited by M. Boniuk, pp. 477-490. Kimpton, London, Mosby, St Louis.

Levitt, J. M., de Veer, J. A., and Oguzhan, M. C. (1969). Orbital nodular fasciitis. Arch. Ophthal., 81, 235-237.

Lichtenstein, L. (1964). Histiocytosis X (eosinophilic granuloma of bone, Letterer-Siwe disease, and Schüller-Christian disease). J. Bone Jt Surg., 46A, 76-90.

Liebow, A. A., Carrington, C. R. B., and Friedman, P. J. (1972). Lymphomatoid granulomatosis. Hum. Path., 3, 457-558.

McCormick, G. L., Macaulay, W. L., and Miller, G. E. (1949). Talc granulomas of the eye. Amer. J. Ophthal., 32, 1252-1254.

MacDonald, R., Jr., and Byers, J. L. (1959). Dermoid tumor of the orbit simulating a neoplasm. Amer. J. Ophthal., 47, 863-866.

McPherson, S. D., Jr., Kiffney, G. T., Jr., and Freed, C. C. (1966). Corneal amyloidosis. Amer. J. Ophthal., 62, 1025-1033.

Malik, S. R. K., Gupta, A. K., and Choudhry, S. (1968). Ocular cysticercosis. Amer. J. Ophthal., 66, 1168-1171.

Mathur, S. P., and Mathur, B. P. (1959). Conjunctival amyloidosis. Brit. J. Ophthal., 43, 765-766.

Melmon, K. L., and Goldberg, J. S. (1962). Sarcoidosis with bilateral exophthalmos as the initial symptom. Amer. J. Med., 33, $158-160$.
Milner, R. D. G., and Mitchinson, M. J. (1965). Systemic Weber Christian disease. J. clin. Path., 18, 150-156.

Morgan, G. (1967). Collagen diseases and the eye. MD Thesis $\underline{\underline{\sigma}}$ University of London.

Mortada, A. M. (1968). Orbital pseudo-tumours and parasitic infections. Bull. ophthal. Soc. Egypt, 61, 393-399.

Nielsen, R. H. (1959). Ocular sarcoidosis. Arch. Ophthal. (Chic.)음 61, 657-663.

O'Leary, P. A., and Waisman, M. (1940). Dermatomyositis: a study of forty cases. Arch. Derm. Syph. (Chic.), 41, 1001-1019.

Olurin, O., Lucas, A. O., and Oyediran, A. B. O. (1969). Orbitå histoplasmosis due to histoplasma duboisii. Amer. J. Ophthal. 68, 14-18.

Paufique, L., and Etienne, R. (1953). Pseudo-tumour de l'orbite, Bull. Soc. ophthal. (Paris), 398-404.

Raab, E. L. (1970). IIntraorbital amyloid. Brit. J. Ophthal., 54, 445449.

Rosai, J., and Dorfman, R. F. (1969). Sinus histiocytosis with mas sive lymphadenopathy: a newly recognized benign clinico pathological entity. Arch. Path., 87, 63-70.

Silletti, L. (1967). Colesteatoma dell'orbita. Ann. Ottal., 93, 823-841.

Smith, M. E., and Zimmerman, L. E. (1966). Amyloidosis of the eyelid and conjunctiva. Arch. Ophthal., 75, 42-51.

Stallard, H. B. (1940). A case of chronic granuloma of the lacrymabi sac. Brit. J. Ophthal., 24, 457-459.

Stein, H. A., and Henderson, J. W. (1956). Sarcoidosis of the orbit survey of the literature and report of a case. Amer. J. Ophthal. 41, 1054-1056.

Straatsma, B. R. (1957). Ocular manifestations of Wegener's granulo $\vec{D}$ matosis. Amer. J. Ophthal., 44, 789-799.

Straatsma, B. R. (1958). Eosinophilic granuloma of bone. Trans Amer. Acad. Ophthal., 62, 771-776.

Talal, N., and Bunim, J. J. (1964). The development of malignan? lymphoma in the course of Sjögren's syndrome. Amer. $J$ Med., 36, 529-540.

Tolls, R. E., Mohr, S., and Spencer, W. H. (1966). Benign nodular fasciitis originating in Tenon's capsule. Arch. Ophthal., $85^{\circ}$ 482-483.

Ursan, M., and Ghidrai, E. M. (1957). Pseudo-tumour of the of due to tuberculous spheno-ethmoidal sinusitis with oede (Rumanian). Oftalmologia (Buc), 2, 167-172.

Van Wien, S., and Merz, E. H. (1963). Exophthalmos secondary to periarteritis nodosa. Amer. J. Ophthal., 56, 204-208.

Veirs, E. R., and Davis, C. T. (1958). Fungus infections of the ey and orbit. Arch. Ophthal., 59, 172-176.

Walton, E. W. (1959). Pseudo-tumour of the orbit and polyarteritio nodosa. J. clin. Path., 12, 419-426.

Walton, E. W. (1960). Reticulo-endothelial sarcoma arising in the nose and palate (granuloma gangranescens). J. clin. Path.? 13, 279-286.

Wenger, J., Gingrich, G. W., and Mendeloff, J. (1965). Sclerosin cholangitis - a manifestation of systemic disease. Arch. internMed., 116, 509-514.

Wheeler, J. M. (1931). Exophthalmos associated with diabetes insipidus and large defects in the bones of the skull. Archo Ophthal., 5, 161-174.

Wheeler, M. (1946). Exophthalmos caused by eosinophilic granu loma of bone. Amer. J. Ophthal., 29, 980-984.

Williamson-Noble, F. A. (1954). Diseases of the orbit and its contents secondary to pathological conditions of the nose and paranasal sinuses. Ann. roy. Coll. Surg. Engl., 15, 46-64.

Wilson, J. W., and Plunkett, O. A. (1965). The Fungous Diseases of Man. University of California Press, Berkeley and Los Angeleso

Zimmeıman, L. E. (1964). Lymphoid tumors. In Ocular and Adnexa Tumors: New and Controversial Aspects, edited by M. Boniuk pp. 429-446. Kimpton, London. Mosby, St. Louis.

Zimmerman, L. E. (1967). Discussion of paper by Blodi and Gass Trans. Amer. Acad. Ophthal. Otolaryng., 71, 322-323.

Zizmor, J. (1966). Recent trends in the roentgenographic diagnosis ofN orbital tumors. Trans. Amer. Acad. Ophthal. Otolaryng., 70, 579-606. 